\title{
Debris flows promoted by mechanical deterioration of the ground due to eutrophication of hillside ecosystems
}

\author{
T. Futagami ${ }^{1}$, H. Sakai ${ }^{1}$, K. Kakugawa ${ }^{1}$, A. Fujimoto ${ }^{2}$, \\ T. Fukuhara ${ }^{2}$, Y. Fujiwara ${ }^{3} \&$ S. Sakurai ${ }^{4}$ \\ ${ }^{1}$ Hiroshima Institute of Technology, Japan \\ ${ }^{2}$ University of Fukui, Japan \\ ${ }^{3}$ Taisei Corporation, Japan \\ ${ }^{4}$ Construction Engineering Research Institute Foundation, Japan
}

\begin{abstract}
There are many hazards caused by debris flows and landslides all over the world, and especially in Japan, every year. In June 1999 and August 2005 in Hiroshima prefecture and in July 2009 in Yamaguchi prefecture there were many large hazards of debris flows and landslides owing to torrential downpours. Through the survey of these hazards it seems that there is biodeterioration of the mechanical structures of the ground in the hillsides caused by eutrophication (nutrient enrichment) originating in the transition of ground ecosystems in hillside slopes. The eutrophication promotes microbial activities that deteriorate the mechanical structures of the ground in the hillside slopes. Microorganisms promote the weathering of rocks to soils and cause aggregation of soils by their enzymes. Aggregated structures of soils wet the ground to decrease resistance to landslides. It seems that microbial activities accelerate the occurrence of debris flows. This paper involves the investigation of the above-mentioned relationships between debris flows and mechanical deterioration of the ground due to eutrophication of ground ecosystems in hillside slopes. It was found that the values of the eutrophication indexes are low in the stable slopes and high in the unstable slopes. The values of the stability of ground formation are high in the stable slopes and low in the unstable slopes. Many microorganisms are found in the unstable slopes.

Keywords: debris flow, landslide, microorganisms, eutrophication of ground, biodeterioration of ground, natural hazard, ecological systems, mechanical deterioration of ground, aggregated structure of soils.
\end{abstract}




\section{Introduction}

Many disasters caused by debris flows and landslides on hillsides frequently happen all over the world, and especially in Japan, every year. In June 1999 and August 2005 in Hiroshima prefecture and in July 2009 in Yamaguchi prefecture there were many large hazards of debris flows and landslides owing to torrential downpours.

The survey of these hazards indicates that there are two main factors causing the increase of hazards. The one factor is the contiguity of urbanization of hillsides and streams. Such streams may become torrents in a protracted downpour. Recently there have been many developments of housing sites on these dangerous hillsides and in their vicinities. The other factor is biodeterioration of mechanical structures of the ground in hillside slopes caused by eutrophication (nutrient enrichment) originating in the transition of ground ecosystems in hillside slopes. These two factors increase the hazards of debris flows several times over.

The eutrophication and dampening promote microbial activities that deteriorate mechanical structures of ground in hillside slopes. Microorganisms promote the weathering of rocks to soils and cause aggregation of soils by their enzymes. Aggregated structures of soils wet the ground to decrease resistance to landslides. It seems that microbial activities caused by eutrophication of ground ecosystems in hillside slopes accelerate the occurrence of debris flows.

This paper involves the investigation of the above-mentioned relationships between debris flows and mechanical deterioration of ground due to eutrophication of ground ecosystems in hillside slopes. It was found that the values of eutrophication indexes (Total Carbon and Total Nitrogen) are low in the stable slopes where landslides are not expected and high in the unstable slopes where landslides may be expected. The values of stability of ground formation are high in the stable slopes and low in the unstable slopes. Many microorganisms are found in the unstable slopes.

\section{Eutrophication of ground ecosystems in hillsides slopes}

Ground ecosystems in hillside slopes are modelled as shown in Figure 1. The eutrophication of ground ecosystems in hillside slopes has been advanced by the accumulation of organic detritus originating in litter (dead leaves and branches) and fallen timbers. Although until about forty years ago in Japan, people used to gather dead leaves, sticks and twigs of trees for fuel and compost, in recent years, they do not because of the change of life style and of the production style in agriculture. In recent years, gas, petroleum and electricity have been used for fuel energy instead of trees, and chemical fertilizer has replaced compost in almost all farmlands.

The eutrophication and dampening of hillsides by the accumulation of organic detritus promote microbial activities that deteriorate mechanical structures of ground (see Figure 2). Microorganisms promote the weathering of rocks to soils 


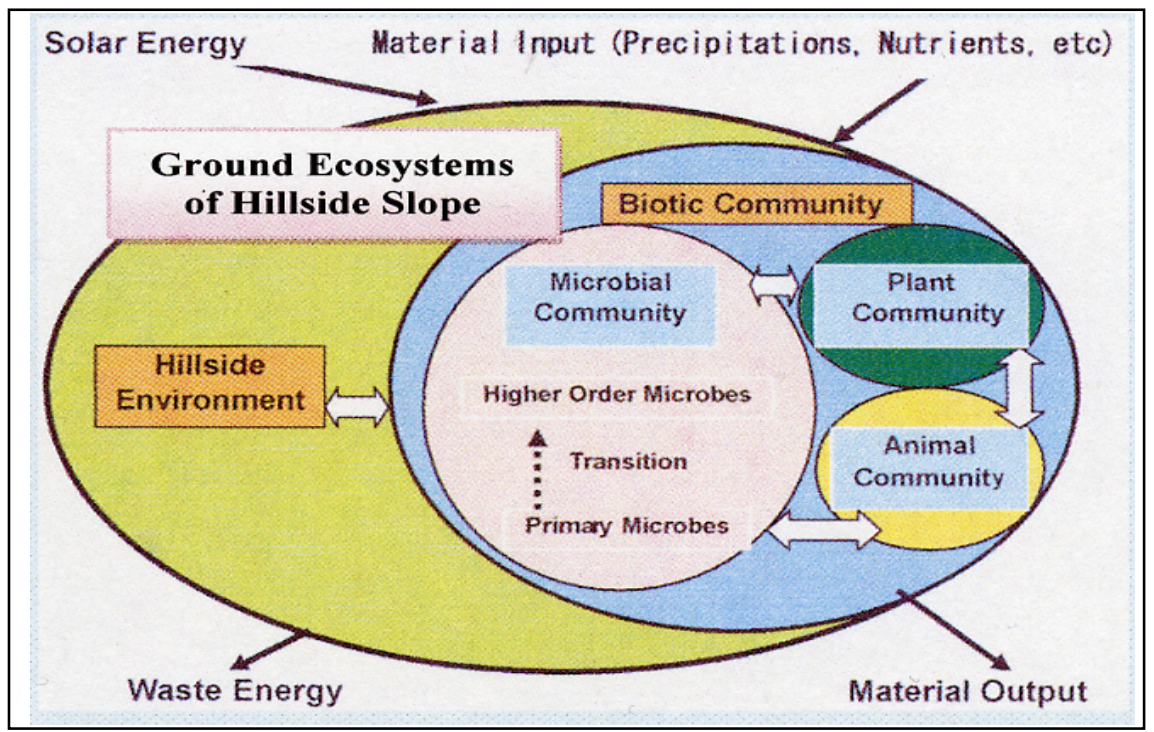

Figure 1: $\quad$ Ground ecosystems of hillside slopes.

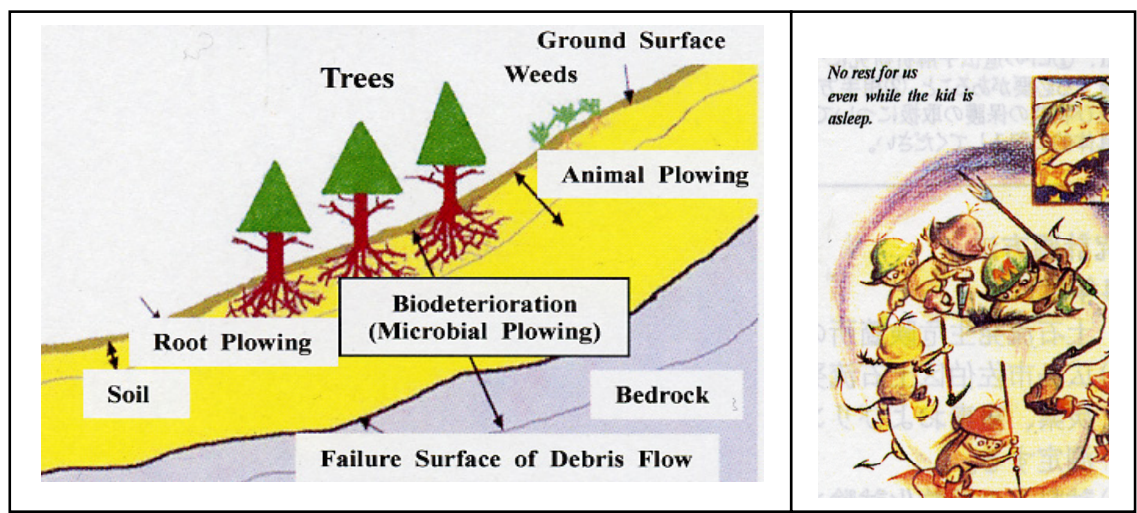

Figure 2: Debris flows and landslides promoted by Figure 3: Microorganisms eutrophication of hillside ecosystems. decompose rocks to soils as in decayed teeth.

and cause aggregation of soils by their enzymes. Microorganisms cause deterioration in ground as in decayed teeth (see Figure 3). Aggregated structures of soils wet the ground to decrease resistance to landslides. It seems that microbial activities caused by eutrophication of hillsides accelerate the occurrence of debris flows. Then occurrence scenario of debris flow promoted by eutrophication of hillside ecosystems is shown in Figure 4. 


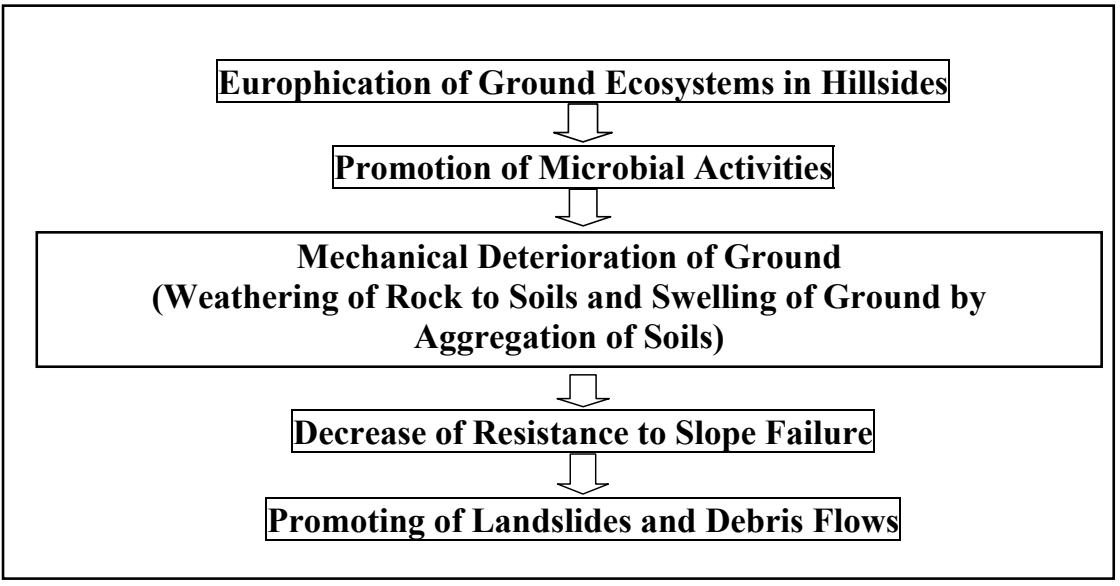

Figure 4: Occurrence scenario of debris flow promoted by eutrophication of hillside ecosystems.

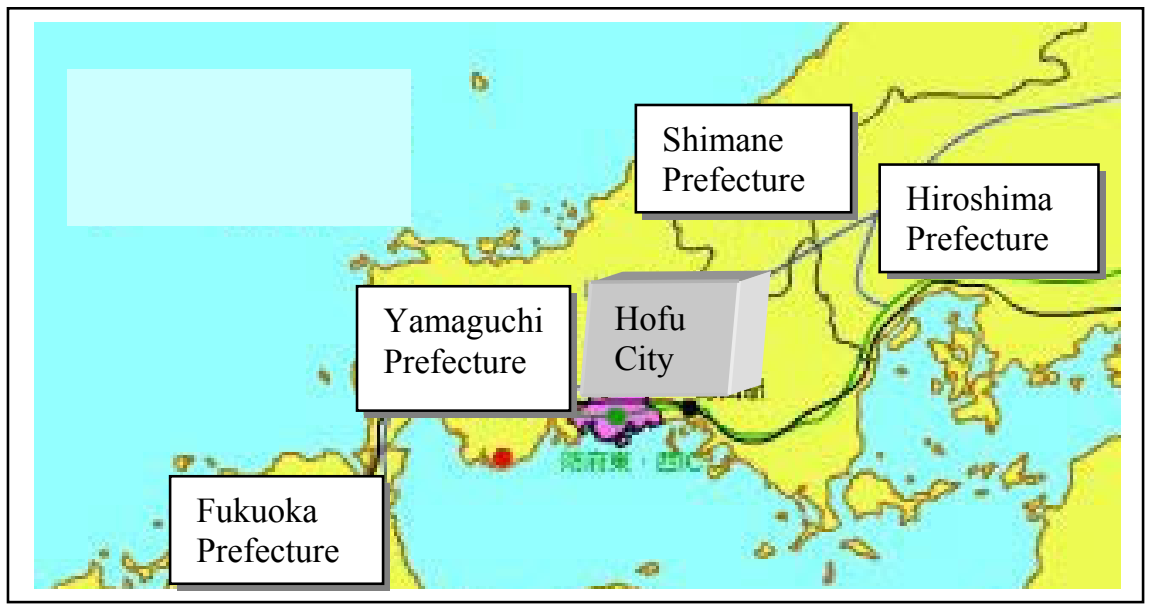

Figure 5: Location map of subsurface investigation of eutrophication in Hofu, Yamaguchi Prefecture.

\section{Investigation on eutrophication of ground ecosystems in hillsides slopes}

\subsection{Investigation sites}

The subsurface investigation on eutrophication was conducted on Suzuya Juuhichi-chiku in Hofu City, Yamaguchi prefecture, in which debris flows were occurred in July, 2009. The location map of the investigation sites is shown in Figures 5 and 6. 


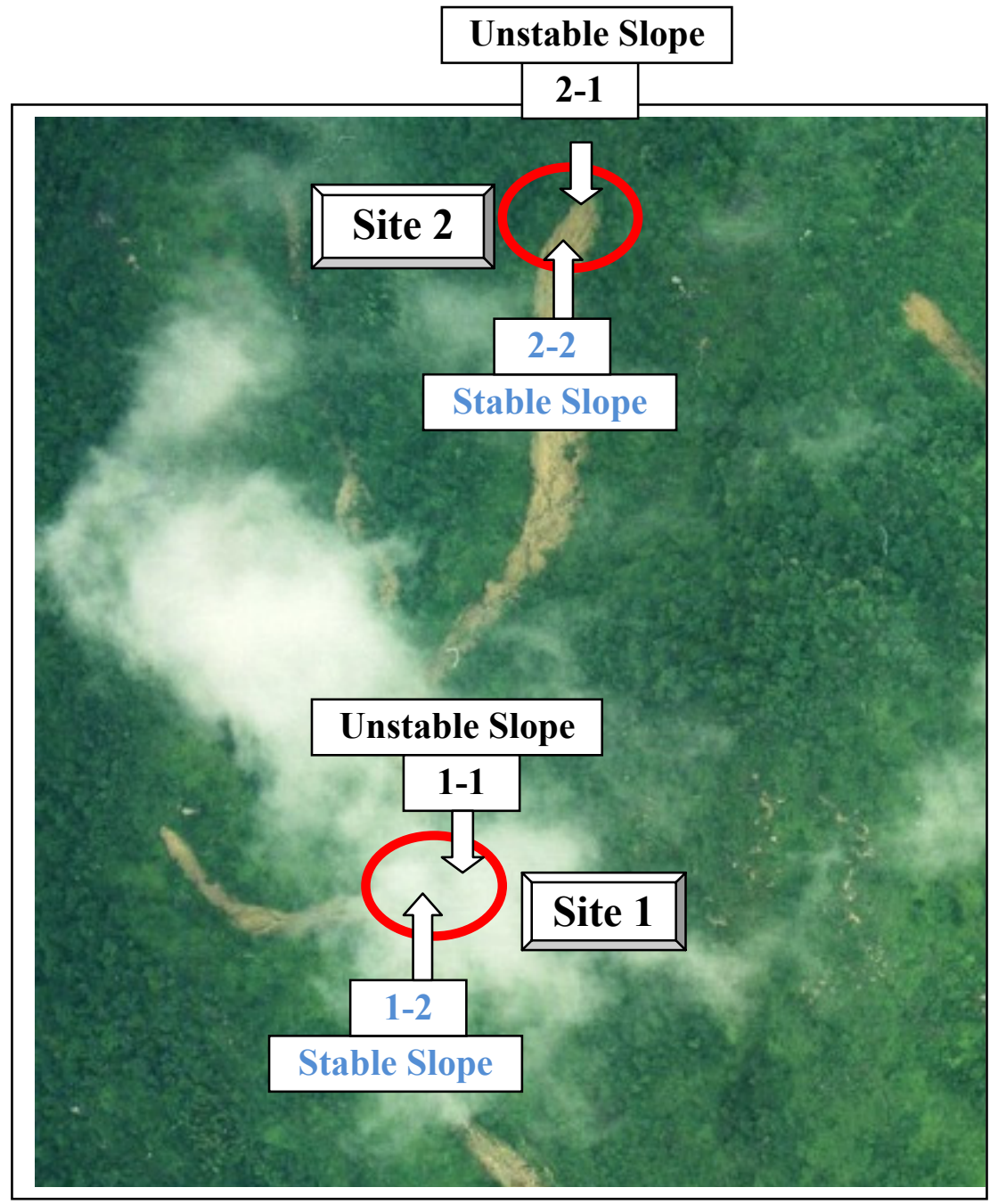

Figure 6: Photograph of subsurface investigation sites of eutrophication in Hofu, Yamaguchi Prefecture.

The data of these investigation sites are shown in Table 1. In Table 1 "Stable Slope" and "Unstable Slope" should be understood as follows:

Stable Slope (Slope where landslide is not expected).

In September, 2005 during torrential rains there were landslides leaving hard bare surfaces, where landslides need not to be expected in the near future.

Unstable Slope (Slope where landslide may be expected).

Slopes where landslide has not recently occurred, and where organic matter is plentiful, the ground is soft and the probability of sliding is plentiful. 
Table 1: $\quad$ Data on Investigation Sites.

\begin{tabular}{|c|c|c|c|c|c|c|}
\hline Site & No & Type of Slope & Plants & $\begin{array}{c}\text { Organic } \\
\text { Detritus } \\
\text { (m) }\end{array}$ & $\begin{array}{c}\text { Slope } \\
\text { Gradient } \\
\left({ }^{\circ}\right)\end{array}$ & Soil \\
\hline \multirow{2}{*}{1} & $1-1$ & $\begin{array}{l}\text { Unstable Slope: } \\
\text { Dangerous slope } \\
\text { for land slide ( } 2 \mathrm{~m} \\
\text { up from landslide } \\
\text { head) }\end{array}$ & $\begin{array}{l}\text { Mixed } \\
\text { forest } \\
\text { mainly } \\
\text { pine } \\
\text { trees }\end{array}$ & $\begin{array}{c}0.10- \\
0.12\end{array}$ & 30 & $\begin{array}{l}\text { Sandy } \\
\text { soil }\end{array}$ \\
\hline & $1-2$ & $\begin{array}{l}\text { Stable Slope: } \\
\text { Safe slope for } \\
\text { landslide ( } 2 \mathrm{~m} \\
\text { lower from } \\
\text { landslide head) }\end{array}$ & Bare & 0 & 30 & $\begin{array}{l}\text { Sandy } \\
\text { soil }\end{array}$ \\
\hline \multirow[b]{2}{*}{2} & $2-1$ & $\begin{array}{l}\text { Unstable Slope: } \\
\text { Dangerous slope } \\
\text { for land slide ( } 2 \mathrm{~m} \\
\text { up from landslide } \\
\text { head) }\end{array}$ & $\begin{array}{l}\text { Mixed } \\
\text { forest } \\
\text { mainly } \\
\text { pine } \\
\text { trees }\end{array}$ & $\begin{array}{c}0.10- \\
0.12\end{array}$ & 30 & $\begin{array}{l}\text { Sandy } \\
\text { soil }\end{array}$ \\
\hline & $2-2$ & $\begin{array}{l}\text { Stable Slope: } \\
\text { Safe slope for } \\
\text { landslide ( } 2 \mathrm{~m} \\
\text { lower from } \\
\text { landslide head) }\end{array}$ & Bare & 0 & 30 & $\begin{array}{l}\text { Sandy } \\
\text { soil }\end{array}$ \\
\hline
\end{tabular}

The data of these investigation sites are shown in Table 1.

The items of the subsurface investigation are as follows:

1) Nutrient Test (Total Carbon(TC) and Total Nitrogen (TN) Test by Using C-N Analyer)

2) Stability Formation of Ground (Dynamic Cone Resistance Test by Using PAND2)

3) Observation of Microoganisms by Scanning Electron Microscope

Observation of microorganisms in subsurface in hillside was conducted by using scanning electron microscope. The low-vacuum freeze drying method (Suzuki et. al. [9]) was used for the preparation of biological specimens.

\subsection{Results of investigation}

The results of the nutrient test are shown Figures 7 and 8. The results of stability formation of ground test are shown in Figures 9-12. The results of observation of microoganisms by scanning electron microscope are shown in Figure 13. It was found that the values of eutrophication indexes (TC and TN) are low in the stable slopes and high in the unstable slopes. The values of dynamic cone resistance are high in the stable slopes and low in the unstable slopes. Many kinds of microorganisms are found in the unstable slopes. 


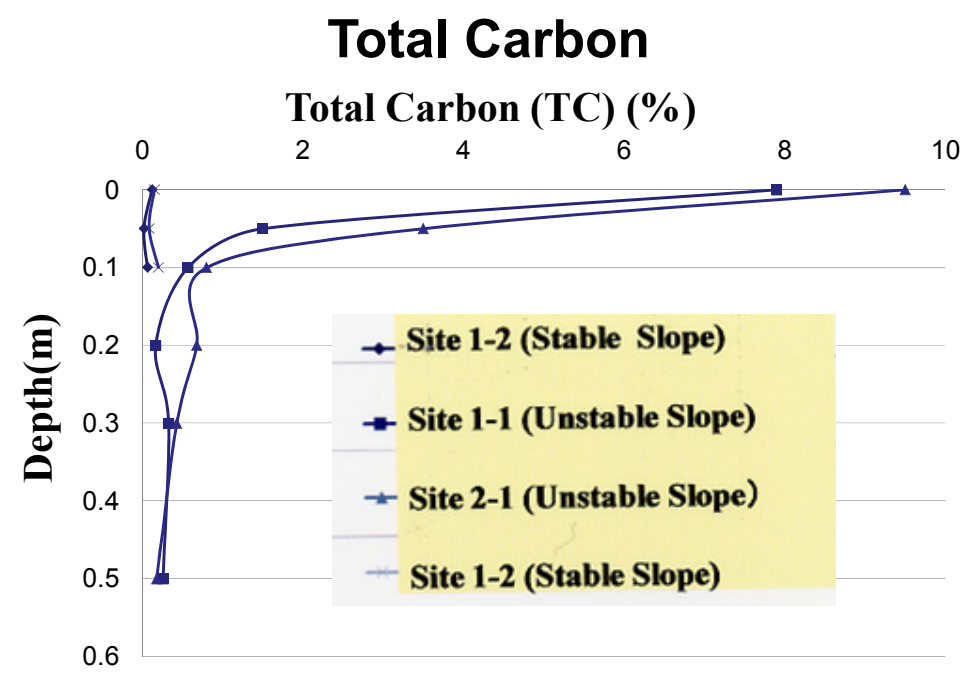

Figure 7: $\quad$ Vertical profiles of total carbon (TC).

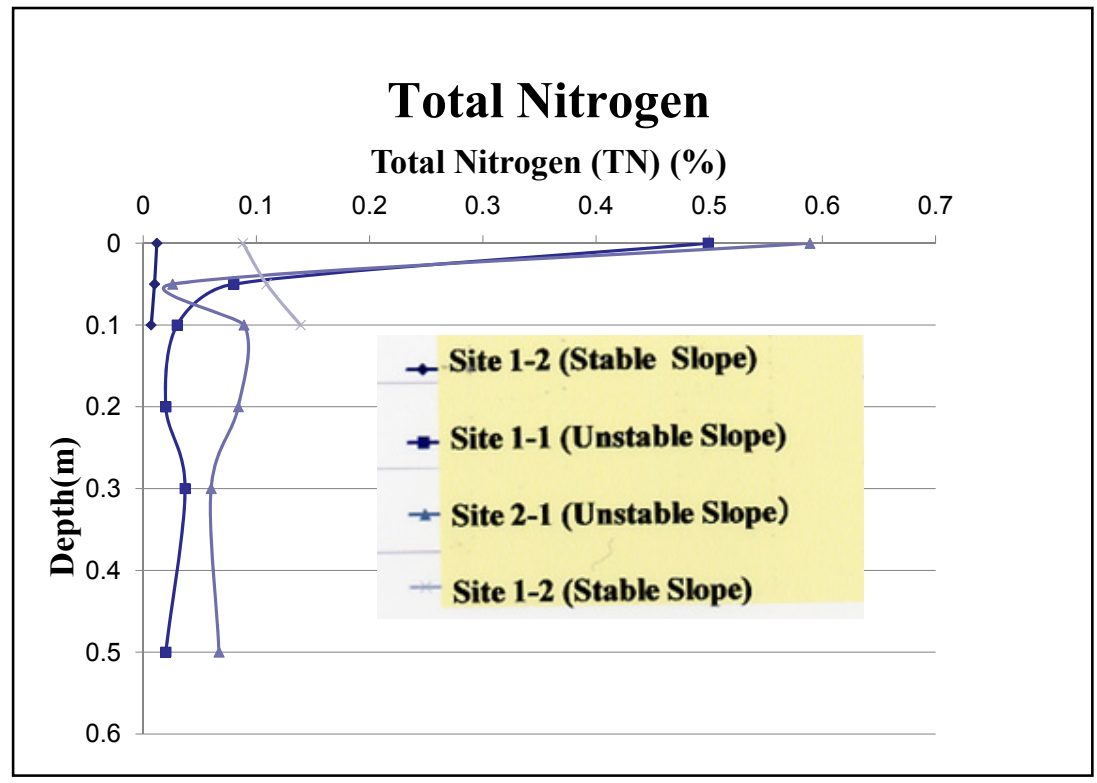

Figure 8: $\quad$ Vertical profiles of total nitrogen (TN). 


\section{Dynamic Cone Resistance (MPa)}

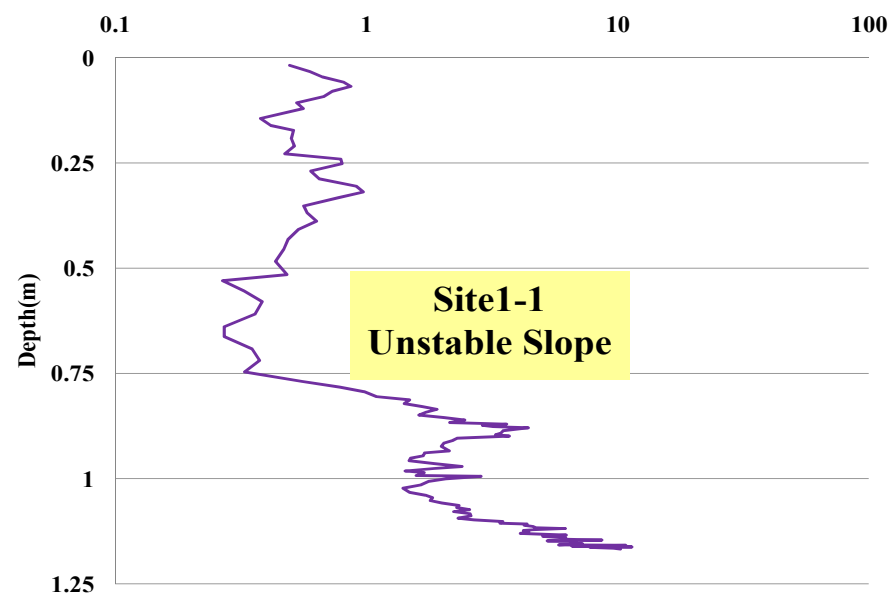

Figure 9: $\quad$ Vertical profile of stability formation of ground in site 1-1.

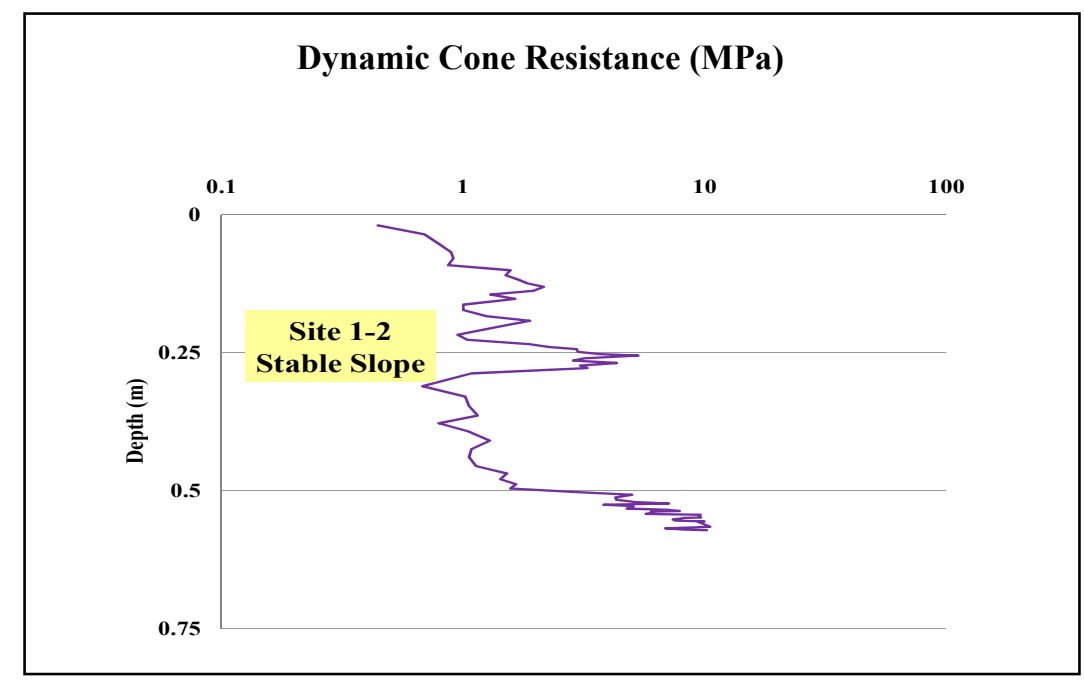

Figure 10: $\quad$ Vertical profile of stability formation of ground in site 1-2. 


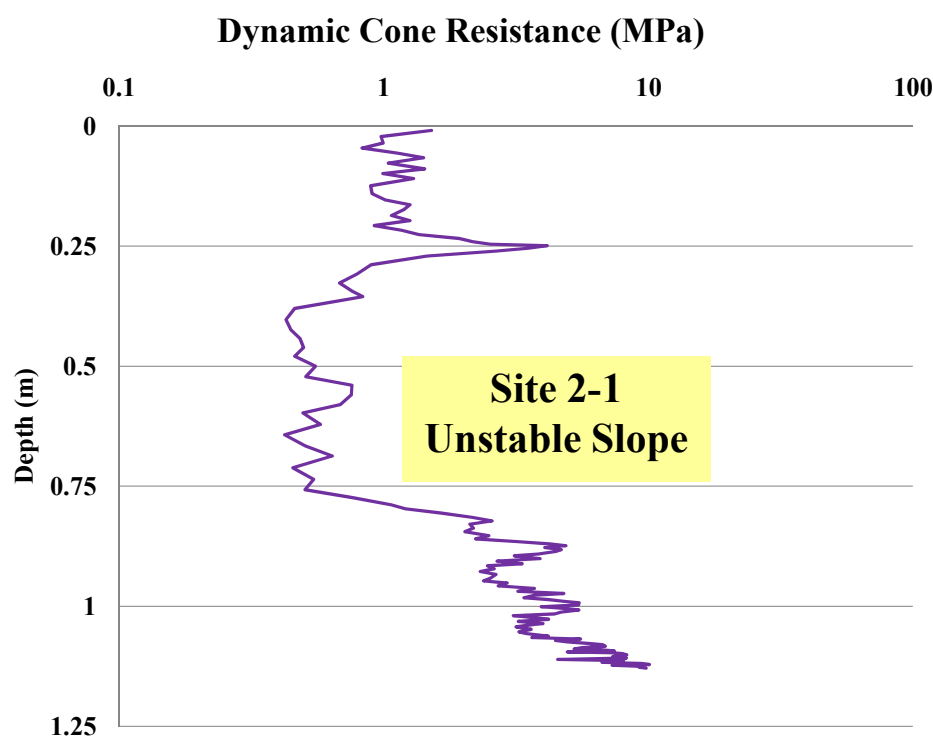

Figure 11: Vertical profile of stability formation of ground in site 2-1.

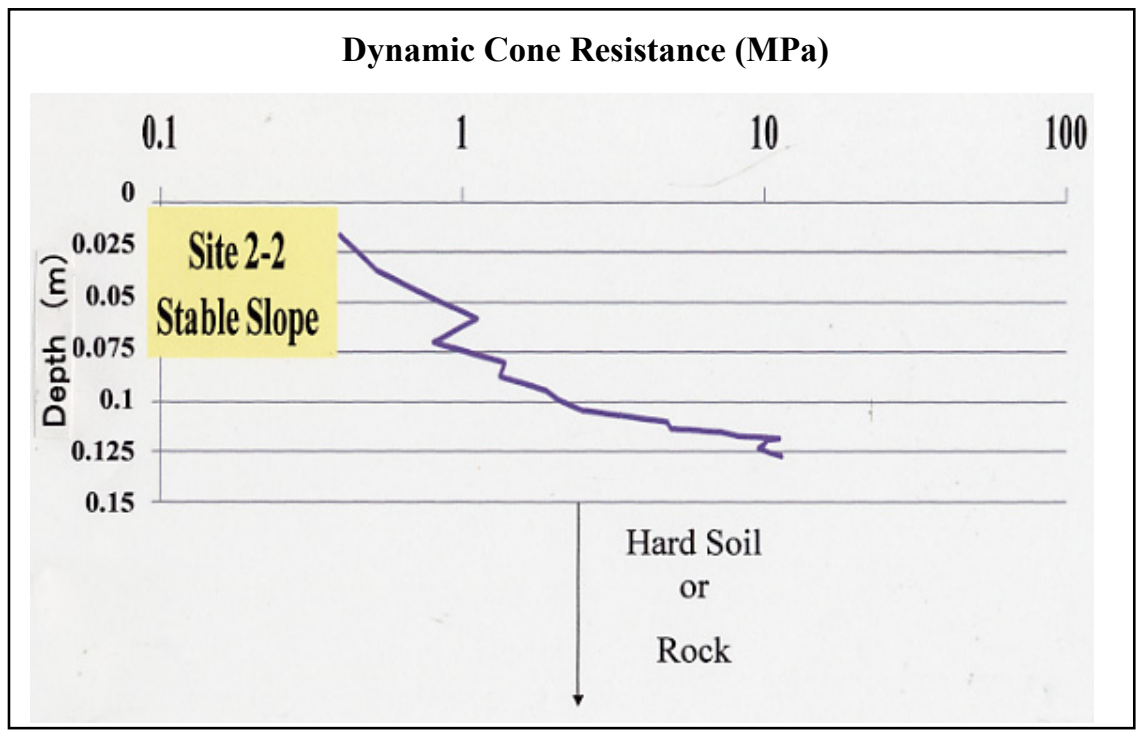

Figure 12: $\quad$ Vertical profile of stability formation of ground in site 2-2. 


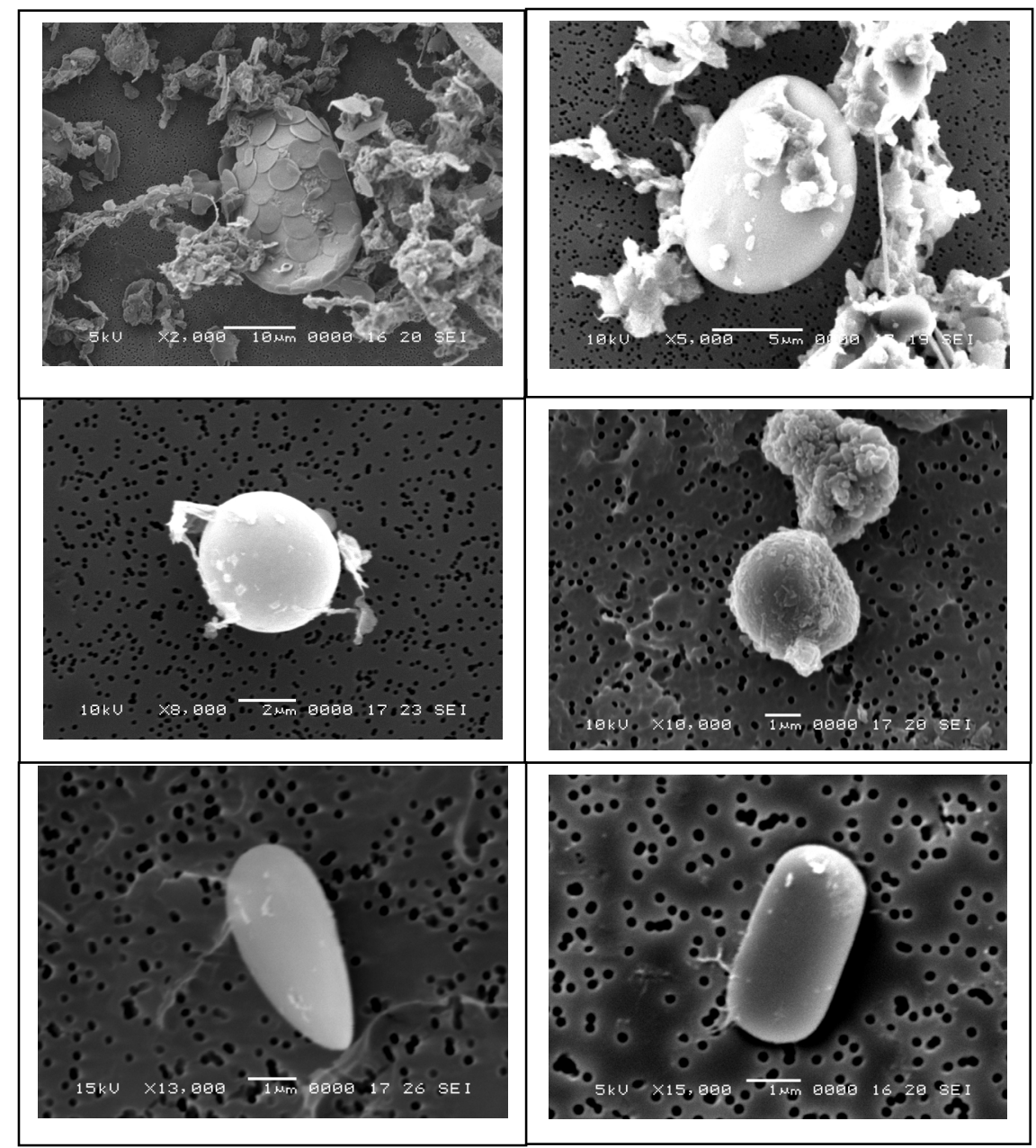

Figure 13: Observed microorganisms in unstable slopes.

\section{Experiment of mechanical deterioration of ground due to eutrophication of slopes}

\subsection{Model slopes}

As illustrated shown in Figure 14, in a vessel comprised of two same boxes two model slopes are made with same gradient $30^{\circ}$ and filled with same $20 \times 9.8 \mathrm{~kg}$ sandy soil. The one box is for stable slopes with bare surface (without organic detritus). The other box is for unstable slopes with eutrophicated surface covered with $0.05 \mathrm{~m}$ depth organic detritus that are eutrophication substances. $200 \mathrm{ml}$ of water was poured from above with watering pot one time over 10 days. 


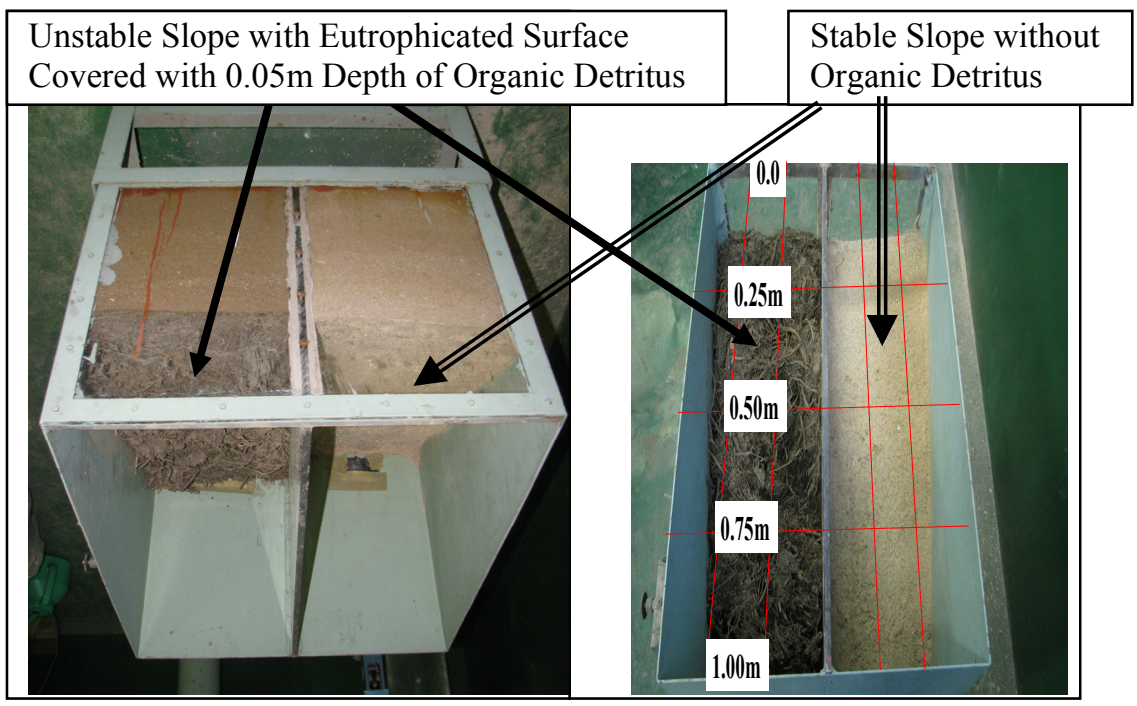

Figure 14: Biodeterioration experiment vessel with two boxes of the same size.

\subsection{Results of biodeterioration experiment}

The readings for stability of ground formation after 45 days of starting time of the experiment are shown in Figure15. It is seen that these readings for stability of ground formation are high in stable slopes with bare surface and are low in unstable slopes with eutrophicated surface covered with eutrophication substances.

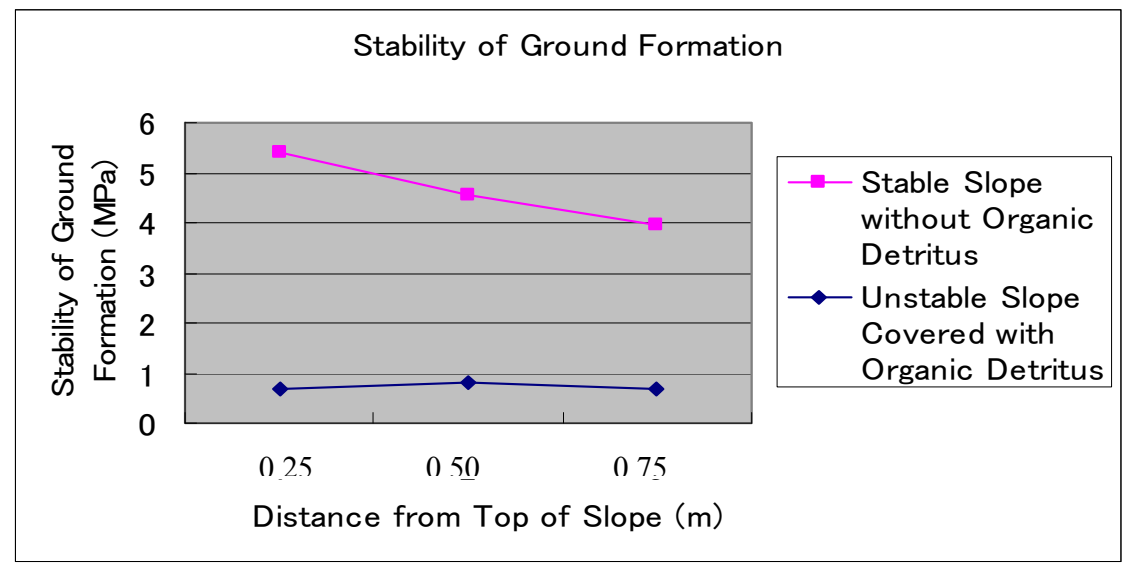

Figure 15: Stability of ground formation. 


\section{Conclusions}

The relationships between debris flows and biodeterioration of mechanical structures of ground in hillsides were studied in this research. Through the results of the site investigation and model experiment on eutrophication of slopes, it was found that biodeterioration of the ground progressed more in the unstable slopes than in the stable slopes. It seems that the eutrophication of slopes promotes mechanical deterioration of the ground and promotes the debris flows.

It is often said that one should not dump refuse at the top of a precipice (Gake no chikaku de gomi wo suteruna). This is to prevent the eutrophication of place potentially dangerous for slope failure. In order to decrease disasters of debris flows and landslides promoted by eutrophication of the ecosystems on hillsides, it is necessary not to nourish or wet dangerous hillsides.

\section{Acknowledgements}

The authors wish to gratefully acknowledge the cordial assistance of Keitaro Oda, Noriise Mori, Naoki Imai, Keita Sumikawa, Koichi Nitta and Yusuke Noda.

\section{References}

[1] Esther, M.E., C. Rodriguez-Jaramillo, M. C., C. Y. Li and Bashan, Y. (2006), "Image Analysis for quantification of bacterial rock weathering", Journal of Microbiological Methods, Elsevier, 64 275-286

[2] Fukuoka M. (1978), "The One Straw Revolution - An Introduction to Natural Farming", Rodale Press,

[3] Futagami T., Ishii Y., Shima S., Yoshikuni H., Kaibara K., Okiyama K., Haga H., (1999), "Heavy Landslides Caused by Transition of Hillside Ecosystems - Microbial Work Owing to Eutrophication of Slopes (Microbial Plowing)", Proceedings of Symposium on Slope Failure and Landslide Problems, Shikoku Branch, Japanese Geotechnical Society, pp 89-98 (in Japanese).

[4] Futagami, T., Terauchi, K., Adachi, T, Ogawa, K. Kono, T., Fujiwara, Y. And Sakurai, S. (2009), "Mechanical Deterioration of Ground Due to Microorganisms Activated by Eutrophication of Ground Ecosystems", Proceedings, of the International Symposium on Prediction and Simulation Methods for Geohazard Mitigation (IS-Kyoto), pp. 45-50.

[5] Howsam, P. (ed.) (1990), "Microbiology in Civil Engineering”, E. \& F.N. Spon, An Imprint of Chapman and Hall, pp. ix-x.

[6] Nanao, J. and Imai, Y. (1984), Mushibakun Daisuki (Do you like Toothache?) Akane Shobo (in Japanese).

[7] Nobunkyo, ed. (1997), "Bokashi Fertilizer Made by Indigenous Microbes”, Video Tape (in Japanese).

[8] Odum E. P. (1983). "Basic Ecology”, CBS College Publishing”.

[9] Suzuki, G. et al. (1995), "A New Drying Method: Low-vacuum SEM Freeze Drying and Its Application to Plankton Observation", Bulletin of Plankton Society of Japan, 42(1), pp. 53-62 (in Japanese). 